\title{
A re-evaluation of Scinaia (Nemaliales, Rhodophyta) in the Azores
}

\author{
K. León-Cisneros $\cdot$ R. Riosmena-Rodríguez $\cdot$ A. I. Neto
}

Received: 8 July 2009 / Revised: 3 May 2010 / Accepted: 12 May 2010 / Published online: 25 May 2010

(C) Springer-Verlag and AWI 2010

\begin{abstract}
The genus Scinaia in the Azores is re-evaluated based on historical and recent collections. A combination of morphological and anatomical diagnostic characters was used for species segregation, and a key for Azorean species determination is presented. Anatomical information associated to the hair development is described for the first time for the genus. The occurrence of S. furcellata and S. interrupta is confirmed for the archipelago. The presence of $S$. acuta is reported for the first time in the Azores, representing a spread from Australia to the N-Atlantic and specifically into the Macaronesian region. Its occurrence in the archipelago and the Canaries is discussed as a possible introduction.
\end{abstract}

Keywords Anatomy · Azores · Morphology $\cdot$ Nemaliales · Scinaia $\cdot$ Taxonomy

Communicated by Inka Bartsch.

K. León-Cisneros $(\bowtie) \cdot R$. Riosmena-Rodríguez Programa de Investigación en Botánica Marina, Universidad Autónoma de Baja California Sur, Apartado Postal 19-B, CP 23080 La Paz, BCS, Mexico e-mail: kcisneros@uac.pt

K. León-Cisneros · A. I. Neto

CIIMAR (Centro Interdisciplinar de Investigação

Marinha e Ambiental), Universidade do Porto,

Rua dos Bragas, 289-4050-123 Porto, Portugal

K. León-Cisneros · A. I. Neto

Secção de Biologia Marinha, Departamento de Biologia, Universidade dos Açores, Campus de Ponta Delgada, Apartado 1422, 9501-801 Ponta Delgada, Açores, Portugal

\section{Introduction}

The genus Scinaia (Nemaliales, Scinaiaceae, Huisman et al. 2004) was established by Bivona-Bernardi (1822) based on Scinaia forcellata, which is now known as $S$. furcellata (Turner) J. Agardh (for name review see Silva 1992: p. 167 and Silva et al. 1996: p. 114).

Widely distributed around the world (Guiry and Guiry 2009), this genus encompasses 43 species, most of them incompletely described. It has been investigated in NW Europe (Maggs and Guiry 1982), Australia (Huisman 1986, 2006; Millar 1990; Huisman and Womersley 1994), Japan (Kajimura 1988, 1991, 1995), Korea (Lee and Ko 2006) and the Gulf of California (León-Cisneros et al. 2009). These authors described the morphological, anatomical and reproductive features used for species diagnosis. The evolutionary scheme proposed by Huisman (1986) encompassing four groups-'Scinaia complanata group', 'Scinaia moniliformis group', 'Scinaia carnosa group' and 'Scinaia furcellata group'-was not followed by Kajimura (1995), but he also did not propose an alternative scheme.

Two species of Scinaia have been recorded for the Azores (Neto 1994): Scinaia furcellata, firstly cited for Terceira island by Schmidt (1929), and S. interrupta (A. P. de Candolle) M. J. Wynne, first recorded for the islands of Faial, São Jorge and Pico by Fredericq et al. (1992). The diagnosis of these species was based mainly on external morphological characters, and the genus has not been studied in the Azores since 1994. In the present study, a re-evaluation of the genus in the area is made, based on recent collections, herbarium material and historical collections, including type specimens. A critical re-assessment of vegetative and reproductive features suitable for species determination is made, and an account of the species identified in the area is provided. 


\section{Materials and methods}

Studied material included fresh collections, historical collections borrowed from AZB and BM, and type material borrowed from BM (herbarium abbreviations as in Holmgren and Holmgren 1998). Fresh specimens were collected intertidally and subtidally (by scuba diving to $30 \mathrm{~m}$ depth) during field surveys in the Azores archipelago (Fig. 1) between 2006 and 2008. Samples were fixed in 5\% buffered formalin in seawater or pressed following standard protocols and housed at AZB (herbarium of the University of the Azores).

For morphological and anatomical studies, herbarium material was re-hydrated using a saturated detergent solution in warm water. For anatomical examination, semipermanent microslides were prepared by mounting thin hand-sections of the thallus in 50\% corn syrup (Karo Best Foods, Englewood Cliffs, USA), after staining in 1\% aniline blue. Measurements of cells and other taxonomically relevant structures were carried out using a calibrated micrometer eyepiece. Photographs were made using a digital camera (Olympus model C5060, Japan) attached to a light microscope (Olympus model BX50F, Japan). Illustration of the specimens' habit was obtained using a HewlettPackard high-resolution scanner. The taxonomic characters commonly used for Scinaia species identification (see Vroom and Abbott 2004; León-Cisneros et al. 2009) were evaluated for the studied material and the more stable and persistent ones were selected for Azorean species segregation, namely, shape and arrangement of utricles in surface

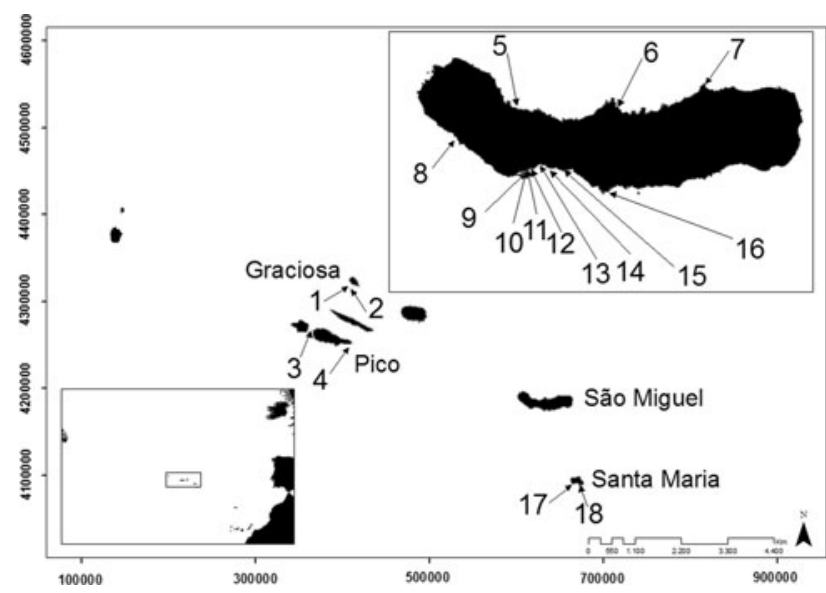

Fig. 1 Collection sites of Scinaia in the Archipelago of the Azores. Graciosa Island: 1 Ponta Branca; 2 Filipe Bay. Pico Island: 3 Madalena channel; 4 Calheta do Nesquim. São Miguel Island: 5 Poços de São Vicente; 6 Porto de Santa Iria; 7 Maia; 8 Feteiras harbour; 9 Moaçor-Ponta Delgada; 10 Pranchinha Bay; 11 Belém Bay; 12 São Roque Islet; 13 Lagoa; 14 Pópulo beach; 15 Viteleiro; 16 Caloura. Santa Maria Island: 17 Restinga; 18 Malbusca view; shape of utricles in transversal view; spermatangium organization; rhizoidal filaments on the cystocarp; and structure of the fusion cell. A dichotomous key to the species from the Azores archipelago was constructed. The systematic arrangement, including the ordinal and lower classification schemes, mainly follows Huisman (2006). The nomenclature used follows Guiry and Guiry (2009).

\section{Results}

On the basis of the combination of the selected diagnostic characters and comparison with type specimens and herbaria material, three species of Scinaia were identified for the Azores (Table 1): S. acuta (Figs. 2, 3, 4), S. furcellata (Figs. 5, 6, 7) and S. interrupta (Figs. 8, 9, 10), see key below.

Key to the species of Scinaia from the Azorean archipelago

\begin{tabular}{|c|c|c|}
\hline $1 \mathrm{a}$ & $\begin{array}{l}\text { Utricles in surface view with a polygonal } \\
\text { appearance (Fig. } 7 \mathrm{~b}, \mathrm{c} \text { ), cystocarp } \\
\text { with rhizoidal filaments (Fig. 10) }\end{array}$ & S. interrupta \\
\hline $1 b$ & $\begin{array}{l}\text { Utricles in surface view with a rosette } \\
\text { appearance (Figs. 3b, 6c), cystocarp } \\
\text { without rhizoidal filaments (Figs. } 4,7 \text { ) }\end{array}$ & 2 \\
\hline $2 \mathrm{a}$ & $\begin{array}{l}\text { Utricles in surface view displaying large } \\
\text { and small polygonal to rounded cells } \\
\text { (Fig. } 3 \text { b); utricles widely obovate } \\
\text { in transverse section (Fig. 3d) }\end{array}$ & S. acuta \\
\hline $2 b$ & $\begin{array}{l}\text { Utricles in surface view displaying } \\
\text { large rounded cells, surrounded by } \\
\text { smaller angular cells (Fig. 6c); } \\
\text { utricles ovoid to obovate in } \\
\text { transverse section (Fig. 6e) }\end{array}$ & S. furcellata \\
\hline
\end{tabular}

Species accounts

Scinaia acuta (Setchell) Wynne 2005: p. 227 (Figs. 2, 3, 4)

Basionym: Pseudoscinaia australis Setchell 1914: p. 121, Fig. 62.

LeCtotype: UC 74793 (Setchell 1914: p. 121, Fig. 62). Type Locality: Port Phillip Heads near Melbourne, Australia (Setchell 1914: p. 122).

Vegetative structure: Thalli erect (Fig. 2), soft to firm gelatinous, unconstricted. Axes terete, up to $3 \mathrm{~cm}$ in height and $0.5-1.5 \mathrm{~mm}$ in diameter, which gradually decrease towards the apical region. Dichotomously branched, up to nine times in two planes, the distance between bifurcations 3-6 $\mathrm{mm}$ and relatively constant throughout the whole thallus. Apices acute (Figs. 2, 3a) with a sunken apical pit. 
Table 1 Diagnostic characters of Scinaia species from the Azores

\begin{tabular}{|c|c|c|c|}
\hline Characters & S. acuta & S. furcellata & S. interrupta \\
\hline $\begin{array}{l}\text { Arrangement of utricles } \\
\text { in surface view }\end{array}$ & $\begin{array}{l}\text { Rosette, large cells not completely } \\
\text { surrounded by small cells }\end{array}$ & $\begin{array}{l}\text { Rosette, large cells } \\
\quad \text { surrounded by small cells }\end{array}$ & Polygonal \\
\hline Shape of utricles in surface view & $\begin{array}{l}\text { Large and smaller cells polygonal } \\
\text { to rounded }\end{array}$ & $\begin{array}{l}\text { Large cells rounded; } \\
\text { small cells polygonal }\end{array}$ & Polygonal \\
\hline Shape of utricles in transversal view & Widely obovate & Ovoid to obovate & Square to oblong \\
\hline Spermatangium organization & Sorus & Sorus & Not sorus \\
\hline Rhizoidal filaments on the cystocarp & Absent & Absent & Present \\
\hline Fusion cell composition & Not observed & $\begin{array}{l}\text { Basal cell, hypogynous } \\
\text { cell and carpogonium }\end{array}$ & $\begin{array}{l}\text { Basal cell, hypogynous } \\
\text { cell and branches, } \\
\text { carpogonium and lowest } \\
\text { gonimoblast cells }\end{array}$ \\
\hline
\end{tabular}

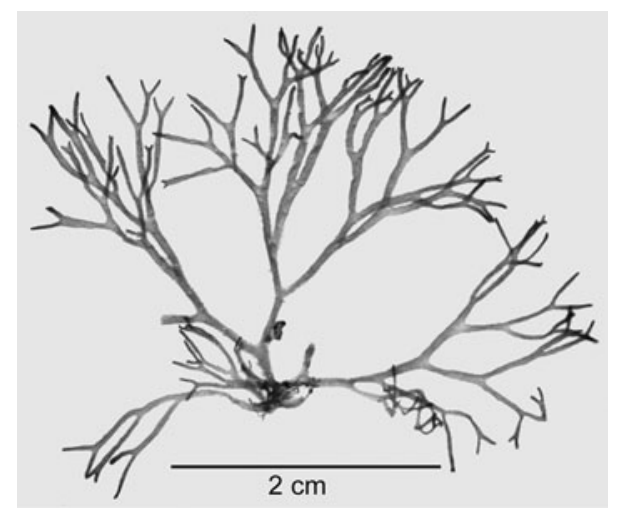

Fig. 2 Habitus of Scinaia acuta (SMA-05-191a, AZB)

The cortex, initially formed by small coloured cells, later develops into utricles and hypodermal cells, which increase in size towards the older region. In surface view, the utricles have a rosette appearance, displaying large (up to $22 \mu \mathrm{m}$ ) and small polygonal to rounded cells, both thickwalled and colourless (Fig. 3b). Small, pigmented, rounded cells, solitary or in groups of three, occur among utricles. These cells represent vestiges of the hairs commonly found near the apices (Fig. 3c).

The compact central axis, 200-250 $\mu \mathrm{m}$ in diameter, not visible to the naked eye, is formed by thick-walled filaments (5-8 $\mu \mathrm{m}$ wide), giving rise to radial thinner medullary filaments $(2-5 \mu \mathrm{m}$ wide). These support $1-3$ layers of pigmented hypodermal cells and an external layer of utricles. In transverse section, the pigmented cells, up to $18 \times 8 \mu \mathrm{m}$, can be spherical, pear-shaped or elongated. The utricles, widely obovate, measure up to $24 \mu \mathrm{m}$ in length by $30 \mu \mathrm{m}$ in width (Fig. 3d).

SPeRmatangia: Spermatangia organized in random sori along the thallus surface (Fig. 3e). Spermatangial branches comprise 3-4 cells arising from the hypodermal cells; each mother cell produces $1-3$ spermatangia.
Utricles are present between spermatangia (Fig. 3f). Thallus is monoecious.

CARPOGONIAL BRANCH AND CYSTOCARP: The carpogonial branch comprises three cells: basal cell, hypogynous cell and carpogonium (Fig. 4a). The basal cell cuts off lateral branches that subsequently grow and produce the pericarp (Fig. 4b). The hypogynous cell produces two sterile branches, one single celled, the other two celled (Fig. 4c). The carpogonium elongates to form the trichogyne. After fertilization, the trichogyne decays and several gonimoblasts arise directly from the carpogonium (Fig. 4b) and develop to produce a compact gonimoblast mass (Fig. 4d, e). As the cystocarp matures, it becomes broadly pyriform to spherical, measuring up to $100 \mu \mathrm{m}$ in diameter.

TETRASPOROPHYTE: Unknown.

ECOLOGICAL OBSERVATIONS: Never abundant, the epilithic gametophytes were found in June in rocky subtidal habitats, at a depth of $14 \mathrm{~m}$.

Specimens examined: Santa Maria Island: Restinga, $14 \mathrm{~m}$ on rocky bottom, coll. N. Álvaro and A. Amaral, 22-Jun-2005 (AZB, SMA-05-191a-b).

\section{Scinaia furcellata (Turner) J. Agardh 1851: p. 422}

(Figs. 5, 6, 7)

Basionym: Ulva furcellata Turner 1801: p. 301, pl. I Fig. A.

HolotyPe: BM 000774967 (Turner 1801: p. 301, pl. I Fig. A).

TyPe Locality: Sheringham, Norfolk, England (Silva et al. 1996).

HOMOTYPIC SYNONYM AND REFERENCES FOR THE AZORES: S. furcellata (Turner) Bivona-Bernardi (Schmidt 1929: p. 110; Schmidt 1931: p. 37, 87; Audiffred and Weisscher 1984: p. 27; South and Tittley 1986; Neto 1994: p. 23). S. forcellata (Turner) Bivona-Bernardi (Audiffred and Prud'homme van Reine 1985: p. 47). 

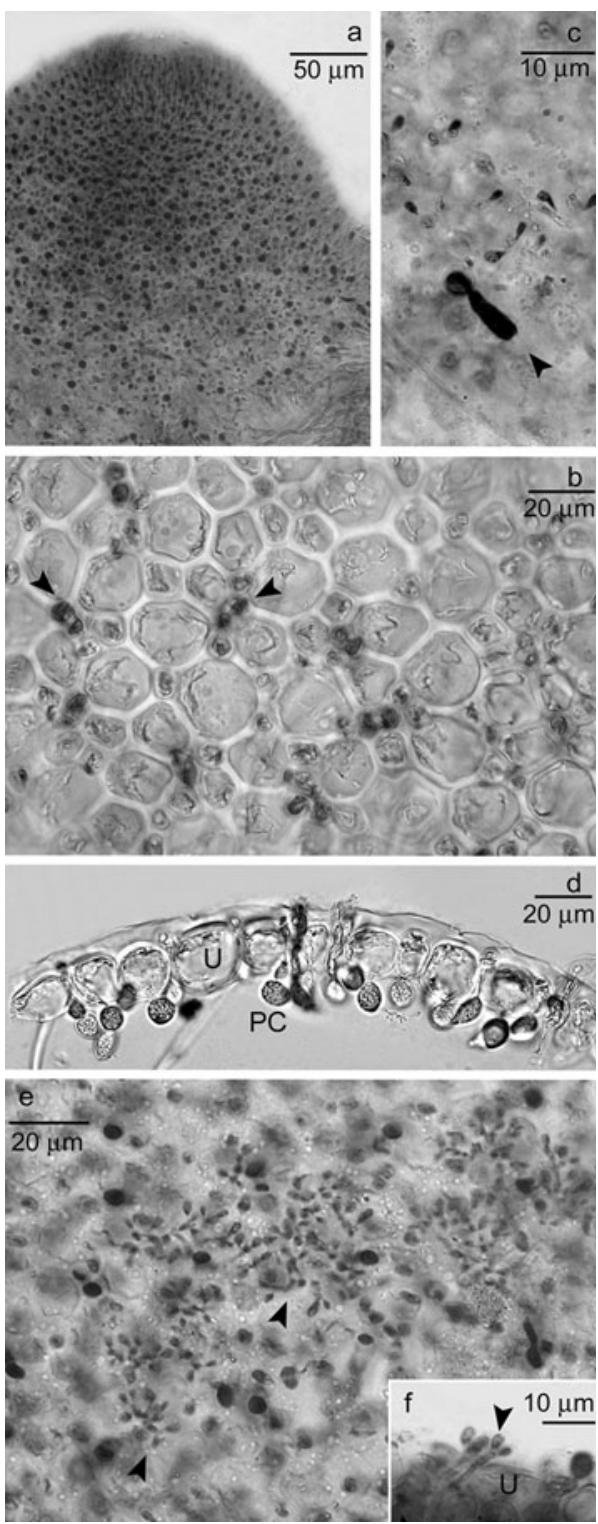

Fig. 3 Scinaia acuta. a Apical morphology showing abundant small pigmented cells. b Surface view of cortex showing the rosette appearance, displaying large and small polygonal to rounded cells and small pigmented rounded cells (arrowheads) among utricles. c Superficial view of a hair developed near the apex. $\mathbf{d}$ Transverse section showing spherical to pear-shaped pigmented cells $(P C)$ and widely obovate utricles $(U)$. e Surface view of spermatangial sorus (arrowheads). $\mathbf{f}$ Transverse view of spermatangial sorus showing spermatangial branches (arrowheads) growing among the utricles $(U)$

Vegetative StRuCture: Thalli erect (Fig. 5), soft to firm gelatinous, occasionally constricted at the base of the branches (50\% of the specimens) more frequently near to the basal area, with some proliferations more common around basal and apical areas. Axes terete, $2-8.5 \mathrm{~cm}$ in height and $0.4-4 \mathrm{~mm}$ in diameter, which is relatively constant through the whole thallus. Dichotomously branched (occasionally trichotomously) 5-15
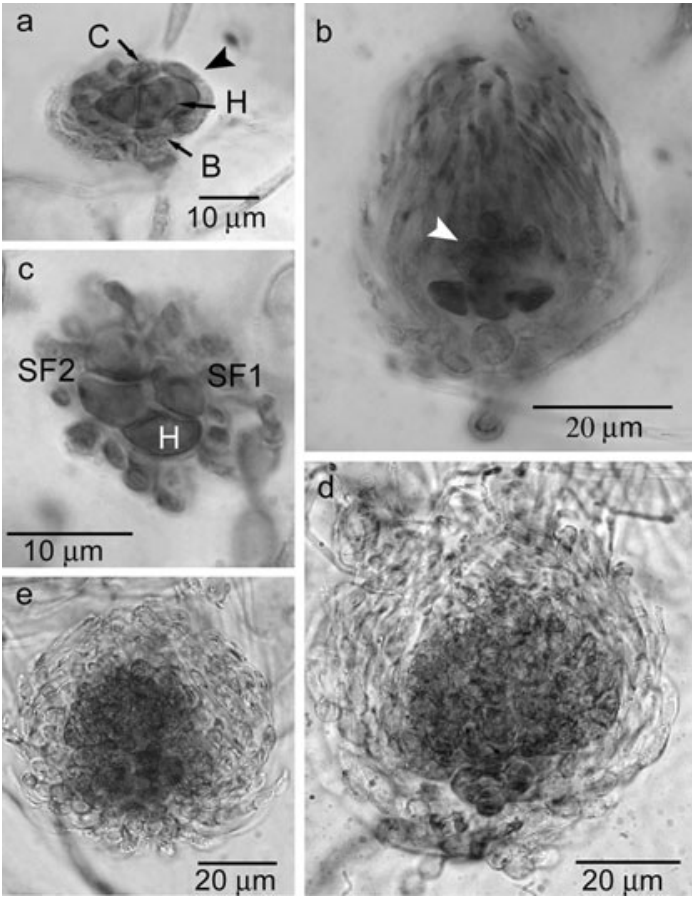

Fig. 4 Cystocarp development of Scinaia acuta. a Carpogonial branch showing the basal cell $(B)$ with initial pericarp (arrowhead), the hypogynous cells $(H)$ and the carpogonium $(C)$. b Immature cystocarp showing gonimoblast filaments arising directly from the carpogonium (arrowhead). c Surface view of the hypogynous cell $(H)$ showing the one-celled branch $(S F 1)$ and two-celled branch $(S F 2)$ sterile filaments surrounded by the pericarp. d-e Developed spherical cystocarp

times in two planes, the distance between bifurcations increasing towards the apex $(1.5-7(-10) \mathrm{mm}$ in the basal area, 2-14 $\mathrm{mm}$ in the apical area). Apices blunt, acute or obtuse (Figs. 5, 6a) with a sunken apical pit.

The cortex, initially formed by small coloured cells, later develops into utricles and hypodermal cells, which increase in size towards the older region. In surface view, the utricles have a rosette appearance, displaying large rounded cells up to $33 \mu \mathrm{m}$, surrounded by smaller angular cells, both thick-walled and colourless. The size of the cells gradually increases from the apex to the mid-basal region, making the rosette appearance more evident in this region (Fig. 6b, c). Small pigmented rounded cells, solitary or in pairs, occur among the utricles. These cells represent vestiges of the hairs commonly found near the apices (Fig. 6d).

The compact central axis, (55-) 77-335 (-370) $\mu \mathrm{m}$ in diameter occasionally visible to the naked eye in formolpreserved specimens, is formed by thick-walled filaments (7-20 $\mu \mathrm{m}$ wide), giving rise to radial thinner medullar filaments $(2-7 \mu \mathrm{m}$ wide). These support 1-3 layers of pigmented hypodermal cells and an external layer of utricles. In transverse section, the pigmented cells, up to $22 \times 20 \mu \mathrm{m}$, can be spherical, pear-shaped or elongated. The utricles, ovoid to obovate (some times elongate in the 


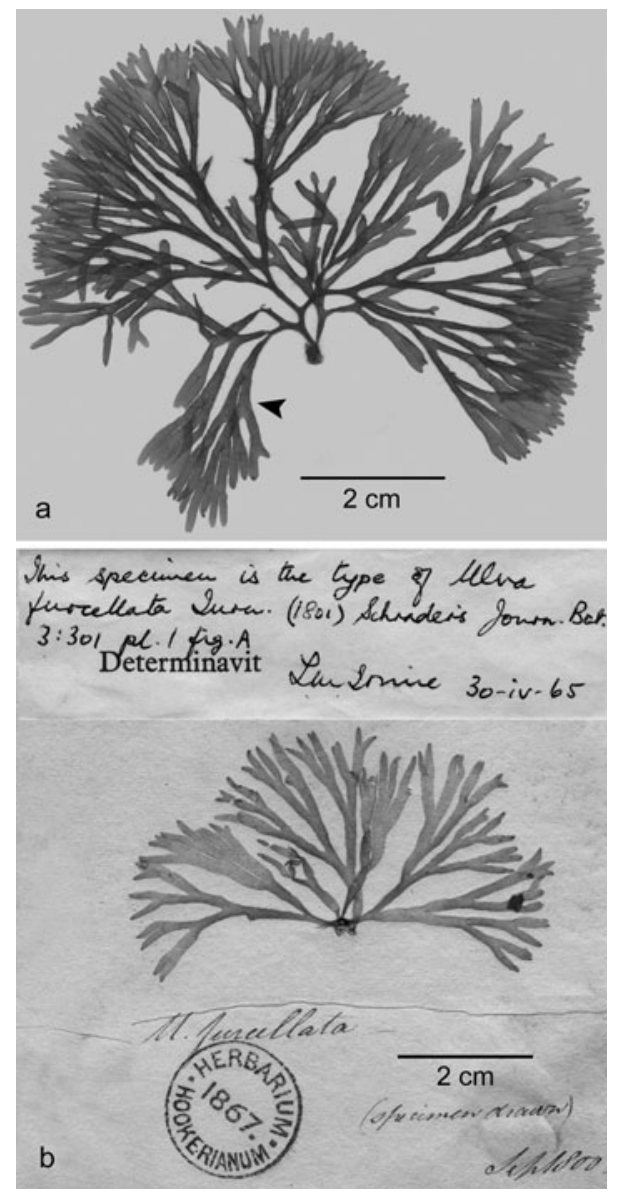

Fig. 5 Habitus of Scinaia furcellata. a Azorean thallus morphology (SMG-91-10, AZB). Cystocarps scattered along thallus (arrowhead). b Scinaia furcellata type material (BM 000774967)

oldest area), measure $11-33 \mu \mathrm{m}$ in length by $9-22 \mu \mathrm{m}$ in width near the apex and $20-48 \mu \mathrm{m}$ in length by $11-31 \mu \mathrm{m}$ in width in the mid-basal region (Fig. 6e, f).

SPERMATANGia: Spermatangia are organized in random sori along the thallus surface (Fig. 6g). Spermatangial branches comprise 3-4 cells arising from the hypodermal cells; each mother cell produces $1-3$ spermatangia. Utricles are present among spermatangia (Fig. 6h). Thallus is monoecious.

CARPOGONIAL BRANCH AND CYSTOCARP: The carpogonial branch comprises three cells: basal cell, hypogynous cell and carpogonium (Fig. 7a). The basal cell cuts off lateral branches that subsequently grow and produce the pericarp (Fig. 7b). The hypogynous cell produces two sterile branches, one single celled, the other two celled (Fig. 7c). The carpogonium (Fig. 7d) elongates to form the trichogyne. After fertilization, the trichogyne decays and several gonimoblasts arise directly from the carpogonium (Fig. 7e), and develop to produce a compact gonimoblast mass (Fig. 7f). A fusion cell is formed by the basal cell, hypogynous cell and fertilized carpogonium; the hypogynous branches, probably with a nutritive function, do not fuse (Fig. 7g). As the cystocarp matures, it becomes broadly pyriform to spherical, measuring $164-249 \mu \mathrm{m}$ in diameter. Young carpogonial branches and developing cystocarps can be seen scattered along the thallus; mature cystocarps are conspicuous to the naked eye.

TETRASPOROPHYTE: Filamentous, only known from culture studies (Boillot 1968, 1969; Kornmann and Sahling 1980).

ECOLOGICAL OBSERVATIONS: Epilithic gametophytes, never abundant, were found from March to July, November and December in tide pools and sandy/ rocky subtidal habitats, down to a depth of $17 \mathrm{~m}$.

Specimens eXamined: São Miguel Island: Poços de São Vicente, $8 \mathrm{~m}$ deep on rocky bottom, coll. unknown, 15-Jul-1997 (AZB, SMG-97-105); Porto de Santa Iria, $10 \mathrm{~m}$ deep on rocky-sandy bottom, coll. S. Monteiro and P. Rodríguez, 28-Jun-2001 (AZB, SMG-01-54); Maia, tidal pool, coll. R. Ámen, B. Fletcher, M. Parente, S. Monteiro and A. Neto, 28-May-1998 (SMG-98-328); Feteiras harbour, crevice, coll. R. Ámen, B. Fletcher, M. Parente, S. Monteiro and A. Neto, 28-May-1998 (AZB, SMG-98-593); MoaçorPonta Delgada, 8-12 m deep on rocky-sandy bottom, coll. W.F. Farnham and J. Brum, 20-Jul-1994 (AZB, SMG-94-218); Pranchinha Bay, 7-12 $\mathrm{m}$ deep on rocky-sandy bottom, coll. J. Azevedo and A. Neto, 07-Jun-1991 (AZB, SMG-91-10); Belém Bay, 17 m deep on rocky-sandy bottom, coll. F. Wallenstein and J. Brum, 12-Jul-1990 (AZB, SMG-90-228); Lagoa, $9 \mathrm{~m}$ deep on rocky bottom, coll. J. Azevedo and J. Brum, 20-Mar-1990 (AZB, SMG-90-51); Caloura, tidal pool, coll. M. Parente, R. Ámen and S. Monteiro, 24-Nov-1998 (AZB, SMG-98-1436).

Scinaia interrupta (A. P. de Candolle) M. J. Wynne 1989: 131, Fig. 1 (Figs. 8, 9, 10)

Basionym: Ulva interrupta A. P. de Candolle 1807: p. 232.

HolotyPE: G 20070050/1 (Wynne 1989, Fig. 1; LeónCisneros et al. 2009, Fig. 16).

Type Locality: Rade de Brest, Brittany, France (Athanasiadis 1996: p. 34).

HETEROTYPIC SYNONYM AND REFERENCES FOR THE AZORES: Scinaia turgida Chemin 1926: p. 102, Figs. 2 , 3 (Fredericq et al. 1992: p. 2; Neto 1994: p. 24; Tittley and Neto 1994: p. 11).

Vegetative structure: Thalli erect (Fig. 8), soft gelatinous, with occasional proliferations and constrictions at the base of the branches (seen in $13 \%$ of the specimens). Axes terete to ellipsoidal, $1.5-10 \mathrm{~cm}$ in height and $0.9-4 \mathrm{~mm}$ in diameter, which is relatively constant 
Fig. 6 Scinaia furcellata. a Apical morphology. b Surface view of cortex near the apical area showing the diffuse rosette appearance, displaying rounded cells interspersed with small pigmented cells (arrowheads). c Surface view of cortex in the middle region showing the rosette appearance with large rounded cells surrounded by smaller angular cells and the small pigmented rounded cells (arrowheads) among utricles. d Transversal view of a hair developed from a small pigmented cell. e Transverse section in the middle region showing medullar filaments $(M)$, spherical to pear-shaped or elongated pigmented cells $(P C)$ and ovoid to obovate utricles $(U)$.

f Transverse section of the basal region showing elongated utricles $(U)$. g Surface view of spermatangial sorus (arrowheads). h Transverse view of spermatangial sorus showing spermatangial branches (arrowheads) growing among the utricles $(U)$
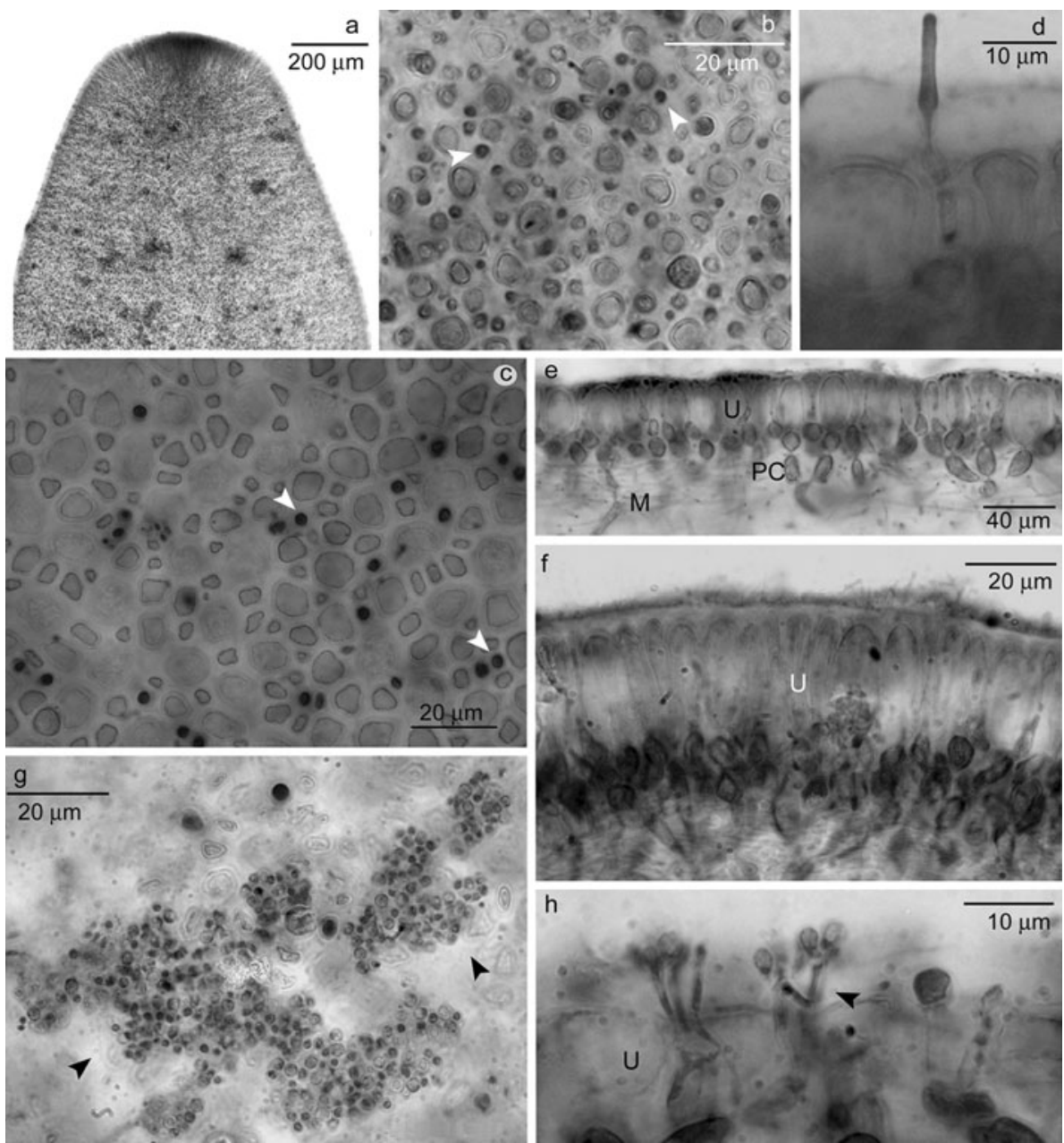

through the whole thallus. Dichotomously branched 4-14 times in two planes, the distance between bifurcations increases towards the apex $(1-8 \mathrm{~mm}$ in the basal area, $2-14 \mathrm{~mm}$ in the apical area). Apices acute or obtuse (Figs. 8, 9a) with a sunken apical pit.

The cortex, initially formed by small and coloured cells, later develops into utricles and hypodermal cells, which increase in size towards the older region. In surface view, the utricles are polygonal in appearance (Fig. 9b, c), displaying tetra-octagonal (some rounded) colourless and thinwalled cells $11-44 \mu \mathrm{m}$ in diameter. The size of the cells gradually increases from the apex to the mid-basal region. Small pigmented rounded cells, solitary or in groups of three, occur among utricles (Fig. 9c). These cells represent vestiges of the hairs commonly found near the apices (Fig. 9d, e).

The compact central axis (Fig. 9d) up to $376 \mu \mathrm{m}$ in diameter, visible to the naked eye on formol-preserved and fresh material, is formed by thick filaments (7-13 $\mu \mathrm{m}$ wide) surrounded by thick walls, giving rise to radial thinner medullary filaments $(2-7 \mu \mathrm{m}$ wide). These support $1-3$ layers of pigmented hypodermal cells and an external layer of utricles. In transverse section, the pigmented cells, up to $15 \times 35 \mu \mathrm{m}$, can be pear-shaped to clavate. The utricles, squared to oblong, measure $20-31 \mu \mathrm{m}$ in length by 11-26 $\mu \mathrm{m}$ in width near the apex and $24-44 \mu \mathrm{m}$ in length by $17-35 \mu \mathrm{m}$ in width on the mid-basal region (Fig. 9f).

Spermatangia: Spermatangia scattered along the thallus surface, mainly in the younger parts, without forming sori (Fig. 9g). Spermatangial branches comprise 3-4 cells arising from the hypodermal cells; each mother cell produces several spermatangia (Fig. 9h). Thalli are monoecious.

CARPOGONIAL BRANCH AND CYSTOCARP: The carpogonial branch, formed near the apices of the thallus, comprises three cells: basal cell, hypogynous cell and carpogonium (Fig. 10a). The basal cell cuts off lateral branches, which eventually will form the pericarp and the rhizoidal filaments (Fig. 10b, d). These later are located at the base of the cystocarp and resemble a root 

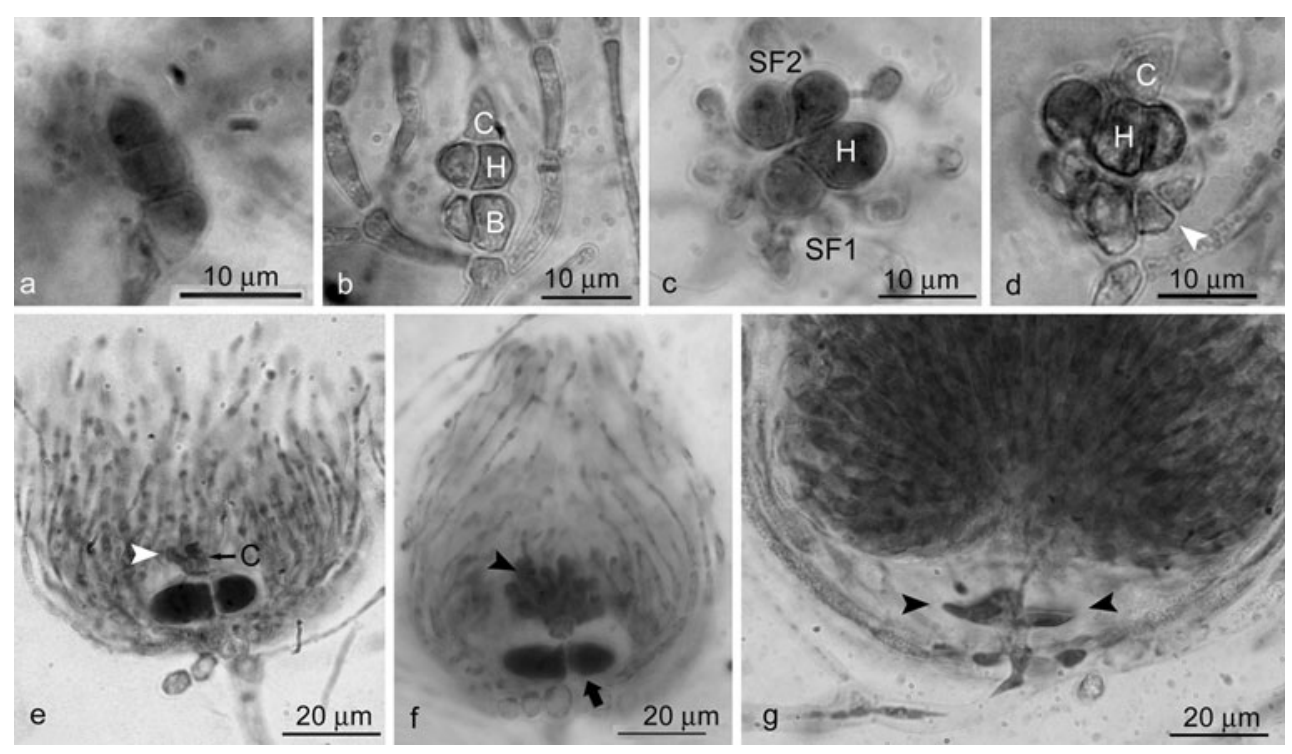

Fig. 7 Cystocarp development of Scinaia furcellata. a Three-celled carpogonial branch. b Carpogonial branch showing the basal cell (B) and the hypogynous cell $(H)$ with initial lateral division and the carpogonium $(C)$. c Surface view of the hypogynous cell $(H)$ showing the one-celled branch $(S F 1)$ and two-celled branch (SF2) sterile filaments. d Developed carpogonial branch showing the initial pericarp

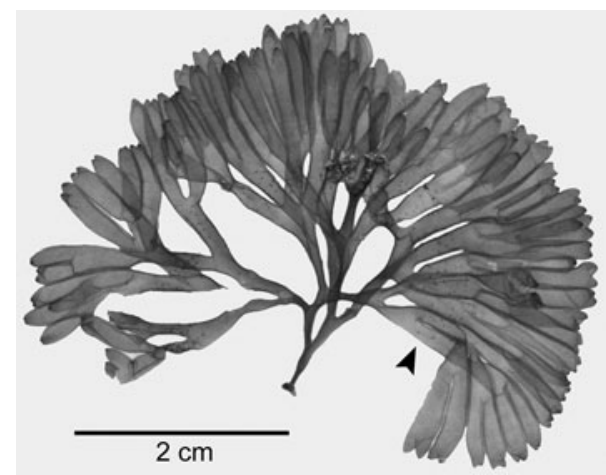

Fig. 8 Habitus of Scinaia interrupta (SMA-05-88, AZB). Cystocarps scattered along thallus (arrowhead)

system (Fig. 10d, i). The hypogynous cell produces two sterile branches, one single celled, the other two celled. The carpogonium elongates to form the trichogyne (Fig. 10c). After fertilization, the trichogyne decays and several gonimoblasts arise directly from the carpogonium (Fig. 10e) and develop to produce a compact gonimoblast mass surrounded by an elongate pericarp (Fig. 10f, g). A fusion cell is formed by the basal cell, hypogynous cell, fertilized carpogonium, the hypogynous branches and ultimately the lower cells of the gonimoblast filaments (Fig. 10f, h). As the cystocarp matures, it becomes pear-shaped to spherical (Fig. 10i), measuring $175-271 \mathrm{~mm}$ in diameter and (arrowhead), the branched hypogynous cell $(H)$ and the carpogonium (C). e Immature cystocarp showing initial gonimoblast (arrowhead) arising directly from the carpogonium $(C)$. f Developing cystocarp showing gonimoblast filaments (arrowhead) and not fused hypogynous branches (arrow). g Fusion cell of mature cystocarp with evident hypogynous branches (arrowheads)

being conspicuous to the naked eye. Older cystocarps occur in the basal region of the thallus.

TETRASPOROPHYTE: Filamentous, only known from culture studies (Boillot 1971; León-Cisneros et al. pers. obs.).

ECOLOGICAL OBSERVATIONS: Gametophytes, never abundant, were found growing epilithically in sandy/rocky subtidal habitats at depths of 5-30 m, from of May to July.

Specimens eXamined: Graciosa Island: Ponta Branca, $30 \mathrm{~m}$ deep on sandy bottom, coll. N. Álvaro, A. Amaral and D. Torrão, 02-Jul-2006 (AZB, GRW-06-510a-i). Pico Island: Madalena channel, $30 \mathrm{~m}$ deep on sandyrocky bottom, coll. D. Villegas, R. Coma and N. Álvaro, 24-Jul-2007 (AZB, PIX-07-1203a). São Miguel Island: Porto de Santa Iria, $12 \mathrm{~m}$ deep on rocky-sandy bottom, coll. K. León-Cisneros and A. Amaral, 17-Jun-2008 (AZB, SMG-08-14); MoaçorPonta Delgada, $15 \mathrm{~m}$ deep on rocky-sandy bottom, coll. J. Brum, 24-Jun-1999 (AZB, SMG-99-849); Pranchinha Bay, 7-12 m deep on rocky-sandy bottom, coll. J. Azevedo and A. Neto, 07-Jun-1991 (AZB, SMG-91-09); Belém Bay, 17 m deep on rocky-sandy bottom, coll. F. Wallenstein and J. Brum, 12-Jul-1990 (AZB, SMG-90-229); Lagoa, $14 \mathrm{~m}$ deep on rockysandy bottom, coll. W.F. Farnham and A. Neto, 25-Jul-1996 (AZB, SMG-96-363). Santa Maria Island: Malbusca, $20 \mathrm{~m}$ deep on rocky-sandy bottom, coll. F. Wallenstein, 07-Jun-2005 (AZB, SMA-05-88). 

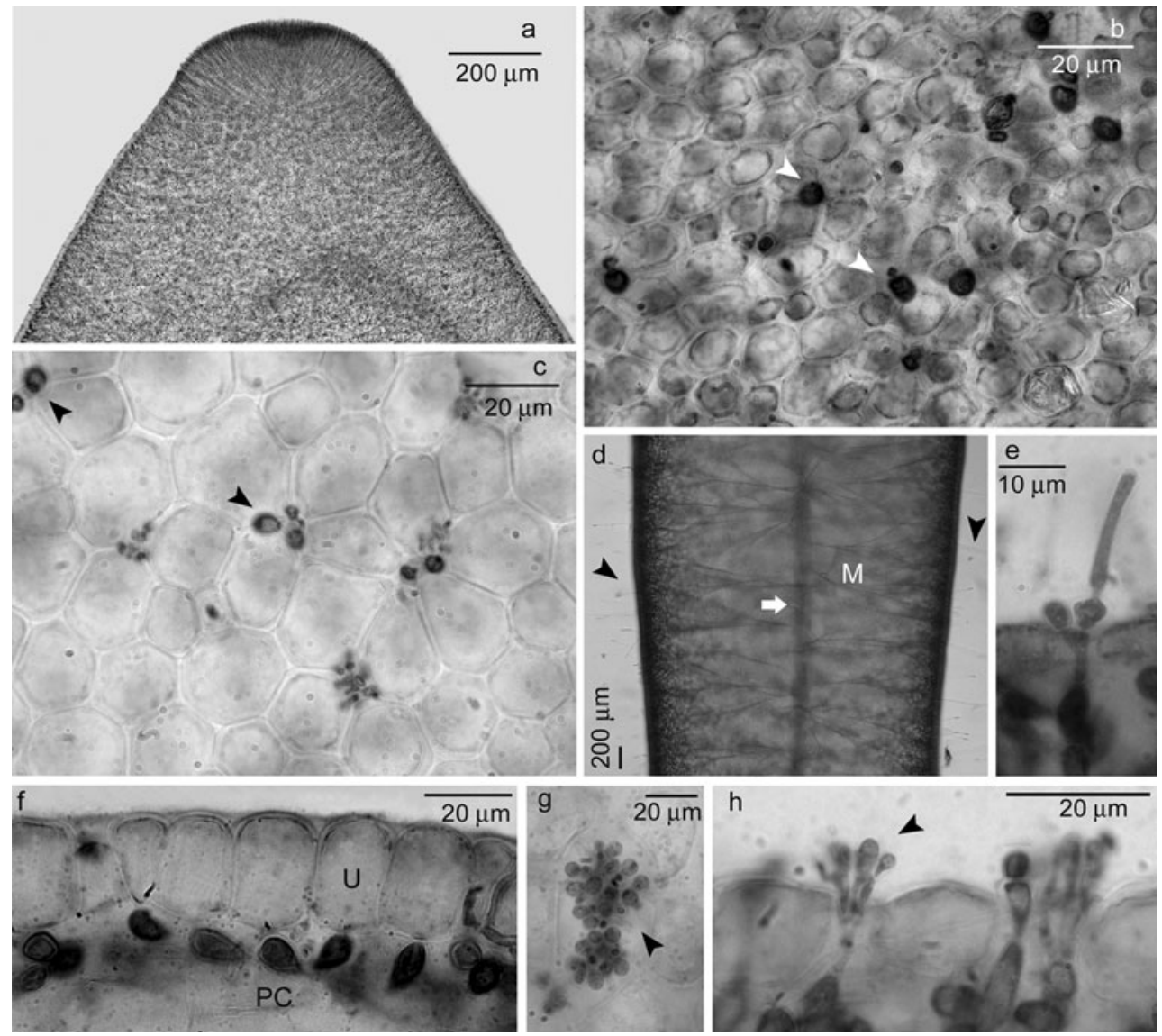

Fig. 9 Scinaia interrupta. a Apical morphology. b, c Surface view of cortex in the apical area (b) and in the middle region, (c) showing the polygonal appearance and the small pigmented cells (arrowheads) among utricles. d Surface view of the thallus showing the central axis (arrow), radial medullar filaments $(M)$ and abundant hairs (arrow-

heads). e Transversal view of a hair developed from a small pigmented cell. f Transverse section in the middle region showing pear-shaped to clavate pigmented cells $(P C)$ and oblong utricles $(U)$. g Surface view of spermatangium (arrowhead). $\mathbf{h}$ Transverse view of spermatangium (arrowhead)

\section{Discussion}

Scinaia acuta is reported for the first time in the Azores, and the occurrence of S. furcellata and S. interrupta in this region is confirmed. Anatomical observations regarding hair development are described here for the first time for this genus. Pigmented cells previously reported as monosporangia (Svedelius 1915; Maggs and Guiry 1982; Huisman 1985, 1986; Kajimura 1988, 1991, 1995; Afaq-Husain and Shameel 2001) or initial spermatangia (Krishnamurthy and Sundararajan 1987) were found to represent the hairs initial development (Figs. 3a-c, 6b-d， 9d-e). Further studies involving other species of the genus are needed to validate this taxonomic character for genus segregation. The anatomical structure of the fusion cell (Fig. 10f-h) is reported for the first time for $S$. interrupta.

Following the classification scheme of Huisman (1986), two morphological groups can be found in the Azores: (1) "S. furcellata group", represented by S. acuta and S. furcellata, characterized by thalli with utricles organized in a

rosette superficial pattern, and (2) "S. carnosa group", represented by $S$. interrupta, encompassing non-flattened plants not always regularly constricted, with utricles organized in a polygonal superficial pattern. No members of the "S. complanata group" and "S. moniliformis group" were found in the Azores. The limits between these morphological groups are, however, unclear (see León-Cisneros et al. 2009). Moreover, as previously discussed by the latter authors, the three species in the Azores show the same reproductive pattern where the hypogynous cells produce two lateral sterile branches (one celled, two celled), a feature that according to Kajimura (1995) should place them into one single group. Scinaia species occurring in the Azores are anatomically distinct and easily separated by microscopic examination of the thallus surface cells, even if only small fragments or incompletely re-hydrated specimens are observed. Morphologically, however, they are very similar and exhibit mainly cylindrical and not regularly constricted thalli. A combination of morphological and anatomical features was used in the present study, 

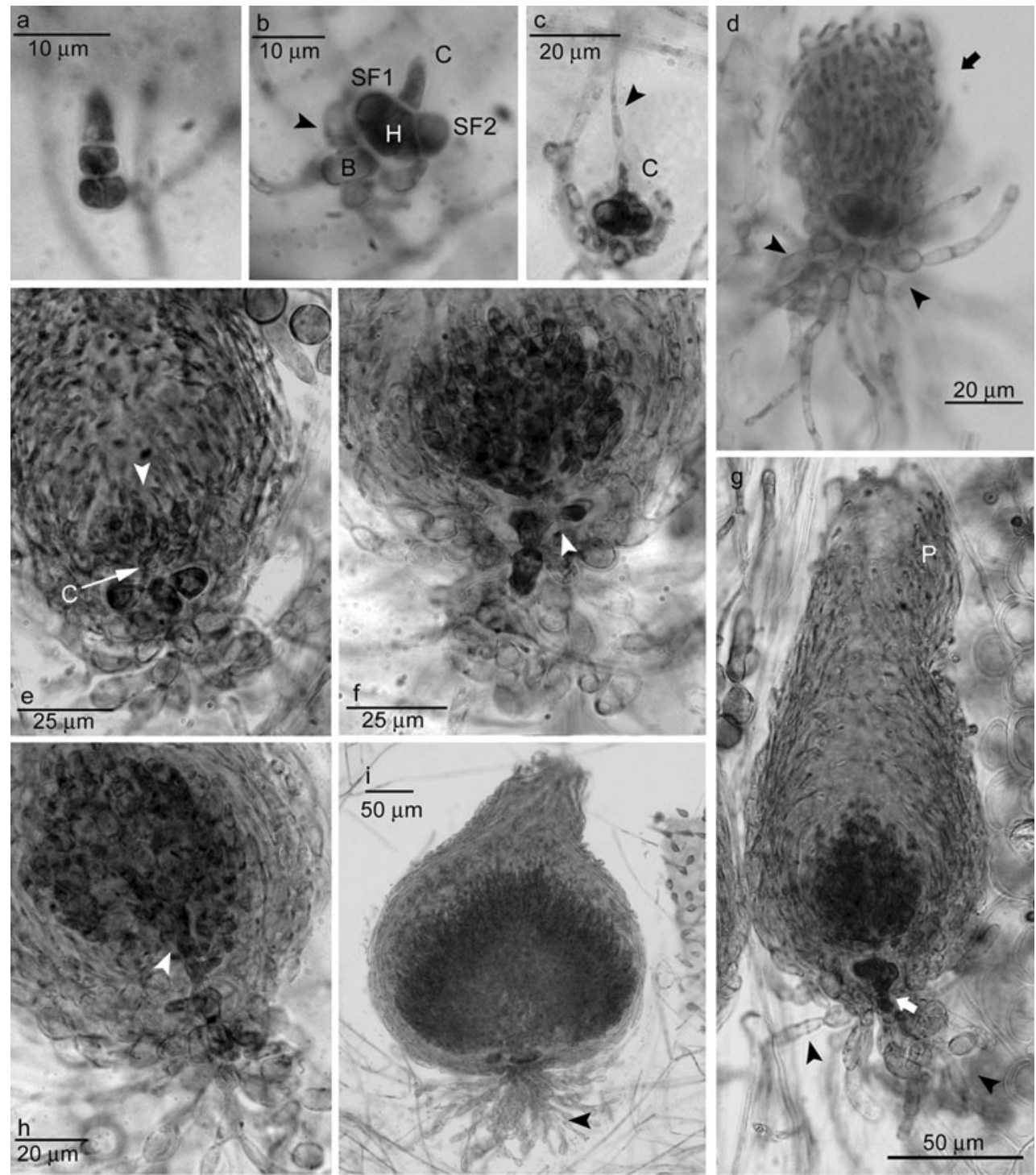

Fig. 10 Cystocarp development of Scinaia interrupta. a Three-celled carpogonial branch. b Developed carpogonial branch showing the basal cell $(B)$ developing the initial pericarp (arrowhead), the hypogynous cell $(H)$ with the one-celled branch $(S F 1)$ and two-celled branch $(S F 2)$ sterile filaments and the carpogonium $(C)$. c Mature carpogonial branch showing the trichogyne (arrowhead) attached to the carpogonium $(C)$. d Immature cystocarp surrounded by the multilayered pericarp (arrow) and rhizoidal filaments (arrowheads) growing from basal

which proved to be efficient in species segregation and is recommended for further studies.

Azorean plants of Scinaia acuta correspond to the morphological original description of Setchell (1914: p. 121, Fig. 62) for Australian material and the descriptions and illustrations of Huisman (1986: p. 284, Figs. 48-51) and Reyes et al. (1993: p. 55, Figs. 23-24) for plants from Australia and the Canaries, respectively.

In general, Azorean Scinaia furcellata correspond to the morphological original description of Turner (1801: p. 301, pl. I fig. A) for material from England and the descriptions cell. e Young cystocarp showing gonimoblast (arrowhead) arising directly from the carpogonium $(C)$. f Developing cystocarp showing a fusion cell with hypogynous branches (arrowhead). g Pear-shaped cystocarp showing the fusion cell (arrow), a developed pericarp $(P)$ and rhizoidal filaments (arrowheads). h Cystocarp showing a fusion cell including the lower cells of the gonimoblast filaments (arrowhead). i Spherical mature cystocarp showing rhizoidal filaments (arrowhead)

and illustrations of Bivona-Bernardi (1822: p. 232, Figs. A-C), Setchell (1914: p. 91, pls 10, 14), Joly (1965: p. 115, Fig. 241), Dixon and Irvine (1977: p. 145, Figs. 54a, b), Maggs and Guiry (1982: p. 520, Figs. 1, 7, 8), and Huisman (1985: p. 405, Figs. 2-9, 10-16) for plants from Italy, Brazil and NE Europe, respectively.

Azorean plants of Scinaia interrupta correspond to the morphological original description of Candolle (1807: p. 232) for material from France, the descriptions and illustrations of the holotype by Wynne (1989: p. 131, Fig. 1) and León-Cisneros et al. (2009: p. 199, Fig. 16) and the 
descriptions and illustrations of Maggs and Guiry (1982: p. 520, Figs. 2-4, 11) and León-Cisneros et al. (2009: p. 195, Figs. 15-27) for plants from NE Europe and Gulf of California, respectively.

Scinaia furcellata and $S$. interrupta, previously recorded for the Azores (Neto 1994) fall within their overall distributional range. The former was firstly described for England and later referred to many other locations, being widely distributed around the world (Guiry and Guiry 2009). The latter, described for France and for long only known for the Atlantic (Guiry and Guiry 2009), was recently reported to occur in the Gulf of California (León-Cisneros et al. 2009) and is likely to have a wider distribution.

Scinaia acuta was originally described for Australia (Setchell 1914), later for the Canaries (Reyes et al. 1993) and now for the Azores, a distribution pattern that suggests its introduction to these Macaronesian archipelagos. There are twelve species of marine algae classified as non-indigenous species for the Azores (Cardigos et al. 2006). Little is known on marine species introductions and invasions to this archipelago, but its high potential for introductions has been widely discussed, considering the increase of the transatlantic leisure boat-traffic stopping at these islands. S. acuta, like Asparagopsis armata Harvey, a well-known invasive species in the Azores, has its origin in the southern hemisphere. Its presence in the Azores suggests a northward expansion of its distribution area in the Atlantic,

Further research involving long-term studies of the qualitative and quantitative evolution of the littoral algal flora analysed in the light of the biogeographic affinities and ecological requirements (tropical, sub-tropical and warm temperate) would help to evaluate and understand the expansion patterns of these marine macroalgae, preferably complemented with physiological studies on their responses to environmental stresses.

Acknowledgments We are grateful to N. Álvaro for providing the study area map, G. Martins and F. Wallenstein for the English revision of the manuscript, I. Bartsch and two anonymous reviewers for their comments and suggestions. This work was partially supported by CIRN (Centro de Investigação de Recursos Naturais, Universidade dos Açores). K. L.-C. acknowledges the scholarship from CONACYT (Consejo Nacional de Ciencia y Tecnología) \# 157904 and from the European Union Programmer of High Level Scholarships for Latin America No.E05D060520MX. We thank Jennifer A. Bryant, curator of The Natural History Museum (BM) for loan of specimens. We also thank the Marine Botany Laboratory staff of the University of the Azores for their diving assistance.

\section{References}

Afaq-Husain S, Shameel M (2001) Structure and reproduction of Scinaia moniliformis pakistanensis var. nov. (Nemaliales, Rhodophyta). Pak J Bot 33:53-68
Agardh JG (1851) Species genera et Ordines algarum, seu descriptiones succinctae specierum, generum et ordinum, quibus algarum regnum constituitur. C.W.K., Gleerups, Lund

Athanasiadis A (1996) Taxonomisk litteratur och biogeografi av Skandinaviska rödalger och brunalger. Algologia, Göteborg, Sweden

Audiffred PAJ, Prud'homme van Reine WF (1985) Marine algae of Ilha do Porto Santo and Deserta Grande (Madeira Archipelago) (Cancap Project Contributions No. 40). Bol Mus Mun Funchal 37:20-51

Audiffred PAJ, Weisscher FLM (1984) Marine algae of Selvagem Grande (Salvage Islands, Macaronesia) (Cancap Project Contribution No. 37). Bol Mus Mun Funchal 36:5-37

Bivona-Bernardi A (1822) Scinaia algarum marinarum novum genus. L'Iride, Giornale di Scienze, Letteratura ed Arti per la Sicilia $1: 232-234$

Boillot A (1968) Sur l'existence d'un tétrasporophyte dans le cycle de Scinaia furcellata (Turner) Bivona, Némalionales. C R Acad Sc Paris Série D 266:1831-1832

Boillot A (1969) Sur le développement des tétraspores et l'édification du gamétophyte chez Scinaia furcellata (Turner) Bivona, Rhodophycées (Némalionales). C R Acad Sc Paris Série D 268:273-275

Boillot A (1971) Sur le cicle de Scinaia turgida Chemin. Bull Soc Bot France 16:68-69

Candolle AP (1807) Rapport sur un voyage botanique et agronomique dans les Départements de l'Ouest. Mém Agric Soc Agric Dép Seine 10:228-292

Cardigos F, Tempera F, Ávila S, Gonçalves J, Colaço A, Santos RS (2006) Non-indigenous marine species of the Azores. Helgoland Mar Res 60:160-169

Chemin E (1926) Sur le développment des spores dans le genre Scinaia et sur la nécessité d'une espèce nouvelle: Scinaia turgida. Bull Soc Bot France 73:92-102

Dixon PS, Irvine LM (1977) Seaweeds of the British Isles V. 1 Rhodophyta Part 1. Introduction, Nemaliales, Gigartinales. British Museum (Natural History), London

Fredericq S, Serrão E, Norris JN (1992) New records of marine red algae from the Azores. Arquipel Life Mar Sci 10:1-4

Guiry MD, Guiry GM (2009). AlgaeBase. World-wide electronic publication. National University of Ireland, Galway. Available from: http://www.algaebase.org/. Accessed 26 May 2009

Holmgren PK, Holmgren NH (1998) [continuously updated] Index Herbariorum: a global directory of public herbaria and associated staff. New York Botanical Garden's Virtual Herbarium. Available from: http://www.sweetgum.nybg.org/ih/

Huisman JM (1985) The Scinaia assemblage (Galaxauraceae, Rhodophyta): a re-appraisal. Phycologia 24:403-418

Huisman JM (1986) The red algal genus Scinaia (Galaxauraceae, Nemaliales) from Australia. Phycologia 25:271-296

Huisman JM (2006) Algae of Australia. Nemaliales. CSIRO Publishing, Canberra

Huisman JM, Womersley HBS (1994) In: Womersley HBS (ed) The marine benthic flora of Southern Australia. Part IIIA. Australia, pp 99-118

Huisman JM, Harper JT, Saunders GW (2004) Phylogenetic study of the Nemaliales (Rhodophyta) based on large-subunit ribosomal DNA sequences supports segregation of the Scinaiaceae fam. nov. and resurrection of Dichotomaria Lamarck. Phycol Res $52: 224-234$

Joly AB (1965) Flora Marinha do litoral norte do estado de São Paulo e Regiões circunvizinhas. Bol Fac Filos Cienc Let Univ São Paulo Ser Bot 21:1-393

Kajimura M (1988) Three new deep-water species of Scinaia (Galaxauraceae, Rhodophyta) from the Sea of Japan. Bot Mar 31:175185 
Kajimura M (1991) Scinaia pseudo-moniliformis sp.nov. (Galaxauraceae, Rhodophyta) from the Sea of Japan. Bot Mar 34:513-520

Kajimura M (1995) The morphology of Scinaia cottonii Setchell (Galaxauraceae, Rhodophyta). Bot Mar 38:535-541

Kornmann P, Sahling PH (1980) Kalkbohrende Mikrothalli bei Helminthocladia und Scinaia (Nemaliales, Rhodophyta). Helgol Meeresunters 34:31-40

Krishnamurthy V, Sundararajan M (1987) Studies on some Indian Nemaliales II. The genus Scinaia Bivona-Bernardi. Seaweed Res Util 10:109-125

Lee Y, Ko YD (2006) The red algal genus Scinaia (Galaxauraceae, Nemaliales) on Jeju Island, Korea. Algae 21:267-281

León-Cisneros K, Riosmena-Rodríguez R, Neto AI, HernándezCarmona G (2009) The red algal genus Scinaia (Nemaliales; Rhodophyta) on the Gulf of California, Mexico: a taxonomic account. Phycologia 48:186-210

Maggs CA, Guiry MD (1982) The taxonomy, morphology and distribution of species of Scinaia Biv.-Bern. (Nemaliales, Rhodophyta) in north-western Europe. Nord J Bot 2:517-523

Millar AJK (1990) Marine red algae of the Coffs Harbour region, northern New South Wales. Aust Syst Bot 3:293-593

Neto AI (1994) Checklist of the benthic marine macroalgae of the Azores. Arquipel Life Mar Sci 12 A:15-34

Reyes J, Sansón M, Afonso-Carrillo J (1993) Notes on some interesting marine algae new from the Canary Islands. Cryptogamic Bot 4:50-59

Schmidt OC (1929) Beiträge zur Kenntnis der Meeresalgen der Azoren. I. Hedwigia 69:95-113
Schmidt OC (1931) Die marine Vegetation der Azoren in ihren Grundzügen dargestellt. Biblioth Bot 25:1-116

Setchell WA (1914) The Scinaia assemblage. Univ Calif Publ Bot 6:79-152

Silva PC (1992) Notas nomenclaturales sobre el Ensayo de Clemente. Anal Jard Bot Madrid 49:163-170

Silva PC, Basson PW, Moe RL (1996) Catalogue of the benthic marine algae of the Indian Ocean. University of California Press, USA

South GR, Tittley I (1986) A checklist and distributional index of the benthic marine algae of the North Atlantic Ocean. British Museum (Natural History) and Huntsman Marine Laboratory. London and St. Andrews, New Brunswick, Canada

Svedelius N (1915) Zytologisch-entwicklungsgeschichtliche Studien über Scinaia furcellata. Nov Acta Reg Soc Sci Ups Suppl 4:1-55

Tittley I, Neto AI (1994) "Expedition Azores 1989": Benthic marine algae (seaweeds) recorded from Faial and Pico. Arquipel Life Mar Sci 12a:1-13

Turner D (1801) Ulva furcellata et multifida, descriptae. J Bot (Schrader) $1: 300-302$

Vroom PS, Abbott IA (2004) Scinaia huismanii sp. nov. (Nemaliales, Rhodophyta): an addition to the exploration of the marine algae of the northwestern Hawaiian Islands. Phycologia 43:445-454

Wynne MJ (1989) Scinaia interrupta (A. DC.) comb. nov., an older name for S. turgida Chemin, and S. pseudocrispa (Clemente) comb. nov., an older name for $S$. forcellata Biv.-Bern. (Galaxauraceae, Rhodophyta). Candollea 44:129-136

Wynne MJ (2005) Scinaia acuta, a new name proposed for Scinaia australis (Rhodophyta). Contr Univ Michigan Herb 24:227-228 